KRISIS KULTURAL PEMUDA DI KAWASAN PARIWISATA
Jurnal Analisa Sosiologi

April 2021, 10 (1): 162-179

\title{
Solikatun $^{1}$, Siti Nurjannah ${ }^{2}$, Nila Kusuma ${ }^{3}$
}

\begin{abstract}
This research aims to find out the cultural crisis among youths in tourism region. This study employed a qualitative research method with phenomenological approach. The result of research showed that the factors underlying the cultural crisis in Kuta society, particularly youths, are innovation or new invention in the society, dissatisfaction with the existing condition, openness to the change, and people's poor consciousness of the preservation of cultures existing. In addition, it is also due to the cultural effect of tourist, the entry of globalization and modernization currents, government supporting more the organization of entertainment events leading to the fading traditions, and more sophisticated technology innovation and social media effect. Cultural crisis occurring in Kuta Village is inseparable from the effect of Kuta village as tourist destination. Such condition makes some of local cultures existing in Kuta changing. On the one hand, some original cultures of Kuta village are still maintained well and not mixed with or affected by external culture (e.g. various forms of art and customary rites). On the other hand, as a tourist destination to which the tourism lovers often come, either domestic or foreign, culture westernization occurs in this village. The westernization effect can be seen from the western-oriented life of tour guide, the youths' fashion style, and tourist facilities resembling foreign lifestyle such cafes.
\end{abstract}

\section{Keywords: Cultural Crisis, Youth, Tourism.}

\begin{abstract}
Abstrak
Penelitian ini memiliki tujuan untuk mengetahui krisis kultural pemuda di kawasan pariwisata.Penelitian ini menggunakan metode penelitian kualitatif dengan pendekatan fenomenologi.Hasil penelitian menunjukkan bahwa faktor yang melatar belakangi timbulnya krisis budaya pada masyarakat khususnya pemuda kuta adalah adanya inovasi atau penemuan baru dalam masyarakat tersebut, ketidakpuasan dengan kondisi yang ada, sikap terbuka pada perubahan, kurangnya kesadaran pada masyarakat akan kelestarian budaya yang ada. Selain itu juga karena pengaruh budaya dari wisatawan, masuknya arus globalisasi dan modernisasi, pemerintah yang lebih mendukung dilakukannya ivent-ivent hiburan yang menyebabkan kesakralan suatu tradisi makin pudar, adanya inovasi teknologi yang semakin canggih, dan pengaruh media sosial. Krisis budaya yang terjadi di Desa Kuta tidak terlepas dari pengaruh desa kuta sebagai destinasi wisata.Kondisi tersebut mengakibatkan sebagian budaya lokal yang ada di

\footnotetext{
${ }^{1}$ Prodi Sosiologi Fakultas Ilmu Sosial dan Politik Universitas Mataram

${ }^{2}$ Prodi Sosiologi Fakultas Ilmu Sosial dan Politik Universitas Mataram

${ }^{3}$ Prodi Sosiologi Fakultas Ilmu Sosial dan Politik Universitas Mataram

${ }^{1}$ solikatun@unram.ac.id
} 
Kuta mengalami perubahan.Disatu sisi masih ada budaya asli desa kuta yang terjaga dengan baik dan tidak tercampur ataupun dipengaruhi budaya luar, diantaranya berbagai bentuk kesenian, upacara-upaca adat. Namn disisi lain, sebagai wilayah destinasi wisata yang sering didatangi oleh penikmat wisata baik lokal hingga mancanegara, menjadikan perubahan budaya yang ada di masyarakat kuta mengalami westrenisasi. Berbagai bentuk pengaruh westrenisasi tercermin dari kehidupan guide tour yang cendrung kebaratbaratan, selain itu cara berpakaian generasi muda, fasilitas-fasilitas wisata yang menyerupai kebutuhan gaya hidup ala mancanegara seperti kafe-kafe.

Kata Kunci:Krisis Kultural, Pemuda, Pariwisata.

\section{PENDAHULUAN}

Budaya adalah suatu cara hidup yang berkembang dan dimiliki bersama oleh sebuah kelompok orang dan diwariskan dari generasi ke generasi. Menurut Edward Burnett Tylor, kebudayaan merupakan keseluruhan yang kompleks, yang di dalamnya terkandung pengetahuan, kepercayaan, kesenian, moral, hukum, adat istiadat, dan kemampuankemampuan lain yang didapat seseorang sebagai anggota masyarakat.Budaya yang ada ditengah-tengah masyarakat memberikan identitas masyarakatnya. Budaya berisi nilai dan norma, adat istiadat, perilaku atau kebiasaan masyarakat dalam berinteraksi dengan alam semesta. Fungsi budaya dalam kehidupan masyarakat sebagai pedoman untuk bersikap dan berperilaku anggota masyarakat.Selain itu budaya dapat memberikan identitas dan juga sebagai alat pemersatu warga masyarakat.

Perwujudan kebudayaan adalah ide atau gagasan manusia seperti nilai dan norma, serta perilaku dan benda-benda yang diciptakan oleh manusia sebagai makhluk yang berbudaya, berupa tradisi, bahasa, peralatan hidup, religi, seni, dan lain-lain yang digunakan untuk memenuhi kebutuhan manusia dalam melangsungkan kehidupan. Masyarakat sebagai subyek budaya dimana masyarakat yang menciptakan budaya, masyarakat juga sebagai obyek budaya dimana budaya ada ditengah-tengah masyarakat atau masyarakat menjadi sasaran dari budaya.Budaya diciptakan, berubah dan berkembang karena manusia sebagai pendukungnya.

Pemuda adalah salah satu anggota masyarakat yang dapat mempengaruhi budaya yang ada di masyarakat.Pemuda merupakan generasi pewaris nilai-nilai budaya yang harus bertanggung jawab mempertahankan 
dan melestarikan tradisi dan kearifan lokal sebagai identitas bangsa.Selain sebagai generasi penerus nilai-nilai budaya, pemuda juga sebagai pondasi, kekuatan moral, dan agen perubahan ke arah pembangungan yang lebih baik.Dalam Undang-Undang Nomor 40 Tahun 2009 tentang Kepemudaan diatur mengenai peran, tanggung jawab dan hak pemuda. Hal ini tercantum dalam Pasal 16: Pemuda berperan aktif sebagai kekuatan moral, kontrol sosial, dan agen perubahan dalam segala aspek pembangunan nasional. Pemuda sebagai obyek atau sasaran budaya, bahkan budaya yang datang dari luar.Hal tersebut memberikan dampak terjadinya dinamika dalam masyarakat terutama dalam aspek buadaya.

Dinamika perkembangan masyarakat terjadi diberbagai aspek kehidupan.Dinamika masyarakat yang terjadi tidak terlepas dari pengaruh globalisasi dan modernisasi.Globalisasi dan modernisasi yang berkembang juga terjadi di kawasan pariwisata.Menurut Murphy (dalam Pitana dan Gayatri, 2019) pariwisata adalah keseluruhan dari elemen-elemen terkait (wisatawan, daerah tujuan wisata, perjalanan, industry, dan lain-lain) yang merupakan akibat dari perjalanan wisata ke daerah tujuan wisata, sepanjang perjalanan tersebut tidak permanen.Masuknya globalisasi dan modernisasi menjadikan masyarakat berkembang kearah modern. Semakin berkembangnya kawasan pariwisata akan memberikan tantangan bagi masyarakatnya termasuk kaum pemuda. Pemuda sebagai salah satu agen perubahan harus mampu menghadapi tantangan global yang semakin komplek.

Hal yang sama juga terjadi di kawasan pariwisata Desa Kuta Kecamatan Pujut Kabupaten Lombok Tengah. Masyarakat kuta mayoritas beragama islam dengan suku sasak. Kuta merupakan kawasan ekowisata yang menyuguhkan panorama alam terutama pantai yang indah, deretan bukit dan budaya lokal.Kuta merupakan Kawasan Ekonomi Khusus (KEK) yang membawa dampak makin berkembangnya daerah seperti infrastruktur, perhotelan, perdagangan, budaya, dan lain-lain.Hal ini yang menyebabkan meningkatkan aspek pariwisata NTB tiap tahunnya. Kontribusi Pariwisata NTB pada tahun 2008 sebesar 1,19 Triliun Rupiah, pada tahun 2015 meningkat menjadi 5,55 Triliun Rupiah, dan pada tahun 2017 meningkat lagi menjadi sebesar 8,9 Triliun Rupiah. Saat progres pembangunan 
Mandalika ini, PBB yang dibayarkan kepada Pemerintah Kabupaten Lombok Tengah sebesar 3,16 Milyar dan BPHTB sebesar 7,76 Milyar Rupiah. Angka yang cukup fantastis dibandingkan dengan daerah-daerah lain di sekitar wilayah Nusa Tenggara Barat (Hartono dan Faozaeni, 2018).Perkembangan bidang pariwisata di Desa Kuta berpengaruh terhadap berbagai aspek kehidupan, baik ekonomi, sosial dan budaya.

Pengaruh dalam aspek ekonomi seperti perubahan mata pencaharian masyarakat setempat dan peningkatan pendapatan.Aspek sosial misalnya perubahan interaksi atau hubungan di dalam masyarakat dan munculnya kelompok atau komunitas baru.Sementara aspek budaya adalah perubahan budaya lokal, budaya konsumerisme, tergantung pada teknologi, menurunnya nilai moral bahkan munculnya budaya baru.Pergeseran atau perubahan budaya lokal yang terjadi terutama di daerah pariwisata seperti Kuta di pengaruhi oleh berbagai faktor, baik internal maupun eksternal.Pergeseran budaya bahkan munculnya budaya baru terutama dikalangan Pemuda Kuta tidak terlepas dari pengaruh globalisasi.Pengaruh globaisasi tidak menutup kemungkinan munculnya budaya globalisasi terutama di kawasan pariwisata.Menurut Ritzer (dalam Djaya, 2012) ada tiga paradigma dalam teori yang berbicara tentang aspek budaya globalisasi, sebagaimana diidentifikasi oleh Jan Nederveen Pieterse, yaitu diferensialisme budaya, konvergensi budaya dan hibridisasi budaya.

Berdasarkan hal tersebut maka dibutuhkan penelitian lebih lanjut mengenai krisis kultural pemuda di kawasan pariwisata. Secara umum tujuan penelitian ini untuk mengeksplorasi mengenai krisis kultural pemuda di kawasan pariwisata.

\section{METODE PENELITIAN}

Penelitian ini menggunakan metode penelitian kualitatif dengan pendekatan fenomenologi.Lokasi penelitian berada di Desa Kuta, Kecamatan Pujut, Kabupaten Lombok Tengah, Provinsi Nusa Tenggara Barat.Subyek dari penelitian ini adalah pemuda desa Kuta, dalam penelitian ini menggunakan teknikpurposeful sampling.Data dikumpulkan melalui wawancara mendalam, observasi dan dokumentasi. Adapun proses analisis dilakukan dalam beberapa tahapan yang meliputi pengumpulan data, reduksi 
data, penyajian data dan kesimpulan/verifikasi data dalam bentuk laporan penelitian.

Data diperoleh dari hasil pengamatan dan wawancara secara mendalam.Dalam kegiatan ini data dan informasi yang diperoleh dicatat setelah melakukan wawancara naturalistik berlangsung.Data dari hasil observasi dipilah-pilah untuk melakukan pendalaman lebih lanjut melalui wawancara mendalam (dept interview) dengan informan kunci sehingga diperoleh pemahaman.Kemudian direduksi dengan cara menyederhanakan dan menyeleksi data yang sesuai dengan permaslahan. Setelah melalui proses reduksi, data yang sudah terseleksi, peneliti sajikan dan analisis dalam penyajian data. Dan yang terakhir setelah data tersusun rapi dan dianalisis dengan benar kemudian ditarik kesimpulan.

\section{HASIL DAN PEMBAHASAN}

\section{Hasil}

\section{Faktor yang melatarbelakangi krisis kultural pemuda di kawasan pariwisata}

Desa Kuta merupakan daerah pariwisata yang ada di kecamatan Pujut Kabupaten Lombok Tengah.Lokasi desa Kuta yang berada dipinggir pantai menjadikan desa Kuta sebagai destinasi wisata dan memiliki kehidupan yang berbeda dengan masyarakat yang lainnya.Perilaku masyarakat pesisir desa Kuta dalam berinteraksi dengan sesama dan alam semesta membentuk budaya yang mengikat masyarakat tersebut.Selain itu, desa Kuta juga mengalami perkembangan kearah yang modern dan kompleks.

Kondisi masyarakat yang dinamis, komplek dan modern berdampak dalam kehidupan masyarakat termasuk aspek budaya.Ditambah letak daerah yang berada di daerah pariwisata mengakibatkan perubahan baik sosial maupun budaya.Perubahan tersebut dialami seluruh kalangan masyarakat tak terkecuali kaum remaja atau pemuda di desa Kuta. Salah satu perubahan yang terjadi dalam aspek budaya adalah gaya hidup pemuda kuta, dimana gaya hidup/ life style pemuda sekarang ini lebih glamor dan lebih menyukai live music. Tak hanya perubahan gaya hidup kaum pemuda, namun perubahan juga terjadi pada tradisi bau nyale, dimana dalam 
pelaksanaan tradisi bau nyale sekarang ini diselenggarakan dengan adanya ivent-ivent music modern berbeda dengan dulu yang dilakukan dengan menampilkan wayang kulit. Selain itu dalam tradisi nyongkolan untuk sekarang ini, terutama perempuan tidak banyak yang mengenakan baju lambung, namun memakai kebaya dan dïringi music yang disebut dengan kecimol.Sehingga, pada masyarakat kuta, dengan budaya yang ada didalamnya telah mengalami perubahan.

Perubahan budaya yang terjadi di masyarakat dapat dilihat pada berbagai pergeseran penerapan budaya-budaya, diantaranya dalam bentuk upacara-upacara tradisional yang mulai mengarah ke sistem yang lebih modern, selain itu dari segi model pakaian telah mengalami perubahan, perubahan bangunan rumah, pola interaksi masyarakat khususnya lawan jenis yang sudah menggunakan teknologi. Bahkan nilai norma yang diterapkan di masyarakat juga mengalami pergeseran, seperti perempuan yang bebas keluar sampai malam.

Perubahan-perubahan budaya yang terjadi dalam masyarakat tentunya disebabkan oleh berbagai faktor.Faktor-faktor tersebut dapat berasal dari internal maupun eksternal masyarakat.Faktor internal perubahan budaya dalam masyarakat dapat berupa sikap masyarakat yang terbuka terhadap budaya baru yang masuk ke masyarakat, ketidakpuasan dengan kondisi yang ada hingga sikap terbuka pada perubahan. Kemudian faktor eksternal yang mempengaruhi faktor perubahan budaya dalam masyarakat diakibatkan karena adanya pengaruh budaya dari wisatawan, masuknya arus globalisasi dan modernisasi, pemerintah yang lebih mendukung dilakukannya ivent-ivent hiburan yang menyebabkan kesakralan suatu tradisi makin hilang, adanya inovasi teknologi yang semakin canggih, pengaruh media sosial. Selain faktor diatas, factor intern yang melatarabelakangi perubahan di desa Kuta adalah kurangnya kesadaran pada masyarakat akan kelestarian budaya yang ada, dan dorongan dalam diri individu untuk berubah agar terlihat lebih modern. Sementara factor ekternalnya selain masuknya budaya luar, juga karena factor budaya yang dibawa individu ketika pergi menuntut ilmu atau merantau. 


\section{Krisis kultural pemuda di kawasan pariwisata}

Desa Kuta merupakan salah satu daerah destinasi pariwisata yang ada di pulau Lombok.Pariwisata sendiri merupakan sebuah tempat atau wilayah yang bisa dikunjungi oleh banyak orang.Pariwisata juga merupakan sumber daya alam, budaya atau tempat dimana para wisatawan dapat menikmati keindahan alam atau fasilitas yang disediakan dan banyak dikunjungi oleh touris.Adapun yang mengatakan pariwisata adalah perjalanan untuk melakukan liburab atau rekreasi.Sebagai salah satu destinasi wisata, desa kuta memiliki modal atau sumber daya untuk menjadi daerah pariwisata.Sumber daya tersebut adalah sumber daya alam dan budaya, bahkan sumber daya manusia sebagai actor penggerak pariwisata tersebut.Sumber daya alam yang menjadi objek pariwisata adalah deretan pantai pasir putih seperti pantai kuta, seger, tanjung aan.Selain itu ada budaya yang menjadi obyek wisata seperti tradisi bau nyale, peresean, dan bangunan rumah adat.

Sumber daya manusia merupakan salah satu modal penting bagi perkembangan suatu daerah seperti daerah pariwisata, dan seringkali kelompok pemuda yang menjadi sorotan sebagai modal terbesar, potensi tenaga kerja dan aktor pengembangan wilayah.Kehidupan masyarakat Kuta yang berada di daerah pariwisata tentunya mengalami perubahan dengan perkembangan pariwisata, terutama kehidupan para pemudanya. Kehidupan para pemuda kuta lebih banyak mengarah pada pengembangan pariwisata baik itu sebagai pemandu wisata (guide) ataupun penjaga villa, membudayakan berbicara dengan bahasa inggris, dan pengembangan budaya lokal.

Selain itu, perubahan kehidupan pemuda kuta juga terlihat dari gaya hidup, bahasa dan tata karma. Gaya hidup pemuda yang sekarang ini lebih ke arah glamor, perempuan sudah biasa keluar malam, dan kurangnya tata karma atau sopan santun anak muda terhadap orang yang lebih tua. Bahkan dengan perkembangan pariwisata yang pesat, disisi lain dampaknya adalah munculnya pekerja anak. Namun disisi lain bagi masyarakat yang memiliki modal, mereka telah membuka café, warung maupun travel.

Kondisi budaya yang ada di Kuta dengan semakin meningkatnya pariwisata untuk saat ini masih tetap dilaksanakan.Tradisi atau kebiasaan- 
kebiasaan terdahulu, ajaran tokoh-tokoh adat masih dijalankan.Budaya yang berkembang di desa Kuta tidak jauh bergeser, hanya saja kesakralan budaya tersebut yang mengalami perubahan akibat diadakannya ivent-ivent oleh pemerintah.Salah satu contoh yang mengalami perubahan adalah tradisi menyilaq (mengundang), dulu mendatangi warga langsung kerumahnya sekarang beberapa sudah menggunakan media sosial.Namun masih dominan masyarakat melakukan menyilaq (mengundang) dengan mendatangi langsung ke rumahnya karena kalau menggunakan handphone dianggap tidak etis. Sehingga dapat dikatakan budaya atau tradisi yang ada di desa Kuta tidak banyak mengalami perubahan, namun perubahan gaya hidup pemuda yang tidak dapat terhindarkan.

Faktor yang melatarbelakangi masih dilakukannya budaya, kebiasaan atau tradisi dan aturan adat ditengah pengembangan pariwisata disebabkan oleh tuntutan dari pengembangan wisata itu sendiri, dimana para wisatawan datang ke desa Kuta dikarenakan ingin melihat dan menyaksikan serta menikmati budaya asli yang ada di desa kuta itu sendiri. Selain itu, karena budaya-budaya tersebut masih diterapkan dan dipertahankan oleh masyarakat dalam kehidupan sehari-hari.

Melihat desa Kuta sebagai destinasi pariwisata yang tak terlepas dari pengaruh arus globalisasi dan modernisasi, namun ada beberapa tradisi yang masih dipertahankan keasliannya oleh masyarakat setempat. Beberapa budaya asli desa kuta masih terjaga dengan baik dan tidak tercampur ataupun dipengaruhi budaya luar diantaranya berbagai bentuk kesenian, upacara-upacara adat, hingga cara berpakaian yang memang masih diterapkan oleh masyarakat kuta. Budaya tersebut adalah gendang beleq, madiq mare, ngapung, tomplek, dan cara berpakaian terutama laki-laki ketika ada begawe dengan mengenakan sarung, bebet dan sapuq.

Budaya-budaya asli yang ada di desa Kuta tersebut tidak berubah atau tidak terpengaruh arus budaya luar dikarenakan masyarakat kuta masih menjaga kelestarian dan mempertahankan kesakralan budaya-budaya tersebut.Hal tersebut dikarenakan budaya asli yang mereka miliki menjadi identitas asli bagi masyarakat kuta.Bahkan dalam pelaksanaan budaya tersebut untuk menjaga kesakralan, masyarakat setempat tidak melibatkan pihak luar dan tidak dipublish.Masyarakat juga masih mempercayai filosofi 
dan tidak ingin melanggar aturan budaya-budaya yang sudah ada.Selain itu juga karena para pemangku adat atau para sesepuh yang melestarikan budaya masih hidup.Hal tersebut menjadi faktor yang kuat mengapa budaya asli yang dimiliki masyarakat desa kuta masih tetap dipertahankan.

Perkembangan pariwisata yang ada di desa Kuta karena dampak globalisasi tentunya membawa perubahan terhadap kehidupan masyarakat. Sebagai wilayah destinasi wisata yang sering didatangi oleh penikmat wisata baik lokal hingga mancanegara, kehidupan masyarakat terutama para pemuda mengalami perubahan lebih kearah westrenisasi. Hal tersebut tercermin dalam kehidupan tour guide yang cendrung kebarat-baratan seperti rambut gondrong dan berwarna merah, bertato serta berpakain ala touris. Namun sampai sejauh ini masih aman-aman saja dan masih wajar bagi masyarakat setempat. Namun disisi lain perubahan gaya hidup pemuda yang meniru budaya barat seperti gaya berpacaran yang bebas dan suka party malam, hal ini yang sangat dikhawatirkan masyarakat. Selain kehidupan pemuda yang mengalami westernisasi, fasilitas-fasilitas wisata juga mengalami westernisasi. Fasilitas yang tersedia menyerupai kebutuhan gaya hidup ala mancanegara seperti hotel dan café. Dimana fasilitas yang disediakan ada live music di café, dan hal tersebut berdampak pada gaya hidup pemuda.

Westrenisasi yang terjadi di masyarakat desa kuta disebabkan oleh adanya pengaruh dari luar yang menjadi tuntutan pekerjaan bagi beberapa masyarakakat, pengaruh budaya luar tersebut diterima dan diterapkan oleh para pemuda sehingga westrenisasi tidak dapat terelakkan.Selain tuntutan pekerjaan, juga karena perkembangan zaman dan globalisasi, dimana perkembangan global ini menjadikan masyarakat mengikuti trend-trend mancanegara.Masyarakat yang sering berinteraksi dengan wisatawan juga menjadi penyebab perubahan yang telah terjadi. Selain karena tuntutan pekerjaan, sikap masyarakat yang tidak peduli atau bodoh amat tentang pandangan orang lain, pengaruh lingkungan, pergaulan, media massa, dan juga karena mengikuti zaman atau trend. Hal tersebut yang meyebabkan terjadinya westernisasi di kalangan anak muda.

Berbagai nilai budaya lokal menjadi sangat penting di tengah persaingan global, sehingga perlu adanya pengembangan budaya lokal agar 
mampu bersaing ditingkat global.Pengemasan budaya lokal menjadi satu hal yang bernilai global disebut dengan glokalisasi.Pada masyarakat kuta beberapa kebudayaan lokal juga mengalami glokalisasi seperti perayaan bau nyale yang dikemas menjadi festival terbuka untuk masyarakat umum.

Fenomena glokalisasi pada kebudayaan lokal yang dimiliki oleh masyarakat kuta disebabkan oleh arus globalisasi, perkembangan teknologi dan informasi yang makin pesat untuk saat ini, banyaknya promosi budaya yang diselenggarakan seperti event-event budaya, selain itu peran pemerintah dalam pemasaran dan pengembangan budaya lokal juga menjadi faktor terbentuknya budaya lokal menjadi glokalisasi.

Perubahan yang terjadi terutama budaya lokal yang ada di desa Kuta ini terjadi sejak perkembangan pariwisata sekitar tahun 2017 an, dan dibarengi dengan kemajuan teknologi.Semenjak desa Kuta menjadi daerah destinasi wisata yang ramai dikunjungi wisatawan baik lokal maupun mancanegara, semenjak itulah desa Kuta mengalami perubahan.

Proses krisis (kemerosotan) budaya di kawasan pariwisata juga tak bisa dihindari, termasuk juga bagi kawasan wisata desa Kuta, kemerosotan budaya terjadi secara berangsur-angsur. Berawal dari perubahan mata pencaharian masyarakat yang dulunya masyarakat bercocok tanam dan beralih ke pariwisata semenjak kemajuan pariwisata.Dimana tujuan awal masyarakat hanya untuk meningkatkan ekonomi dan pemenuhan kebutuhan hidup.Namun tanpa masyarakat sadari perubahan aspek ekonomi tersebut telah mempengaruhi budaya yang ada di masyarakat.Selain itu kurangnya sosialisasi budaya lokal di lembaga-lembaga dasar seperti lembaga keluarga dan lembaga pendidikan juga mengambil peran dalam kemerosotan budaya lokal di tengah masyarakat kuta.Krisis budaya lokal ini bermula dari desa Kuta yang ditetapkan sebagai daerah destinasi wisata dan mengakibatkan munculnya café-café dan hotel, kunjungan wisatawan yang membawa pengaruh budaya baru dan masyarakat kurang mempertahankan budaya sendiri.

\section{Pembahasan}

Desa Kuta merupakan daerah pariwisata yang ada di kecamatan Pujut Kabupaten Lombok Tengah.Lokasi desa Kuta yang berada dipinggir pantai menjadikan desa kuta sebagai destinasi wisata dan berpengaruh 
terhadap berbagai aspek kehidupan masyarakat.Kondisi masyarakat yang dinamis, komplek dan modern berdampak dalam kehidupan masyarakat termasuk aspek budaya.Ditambah letak daerah yang berada di daerah pariwisata mengakibatkan perubahan baik sosial maupun budaya.Perubahan tersebut dialami seluruh kalangan masyarakat tak terkecuali kaum remaja atau pemuda di desa Kuta. Salah satu perubahan yang terjadi dalam aspek budaya adalah gaya hidup pemuda kuta, dimana gaya hidup/ life style pemuda sekarang ini lebih glamor dan lebih menyukai live music. Tak hanya perubahan gaya hidup kaum pemuda, namun perubahan juga terjadi pada tradisi bau nyale, dimana dalam pelaksanaan tradisi bau nyale sekarang ini diselenggarakan dengan adanya ivent-ivent music modern berbeda dengan dulu yang dilakukan dengan menampilkan wayang kulit. Selain itu dalam tradisi nyongkolan untuk sekarang ini, terutama perempuan tidak banyak yang mengenakan baju lambung, namun memakai kebaya dan dïringi music yang disebut dengan kecimol.Sehingga, pada masyarakat kuta, dengan budaya yang ada didalamnya telah mengalami perubahan. Perubahan budaya yang terjadi di masyarakat dapat dilihat pada berbagai pergeseran penerapan budaya-budaya, diantaranya dalam bentuk upacaraupacara tradisional yang mulai mengarah ke sistem yang lebih modern, selain itu dari segi model pakaian telah mengalami perubahan, perubahan bangunan rumah, pola interaksi masyarakat khususnya lawan jenis yang sudah menggunakan teknologi. Bahkan nilai norma yang diterapkan di masyarakat juga mengalami pergeseran, seperti perempuan yang bebas keluar sampai malam.

Perubahan-perubahan budaya yang terjadi dalam masyarakat tentunya disebabkan oleh berbagai faktor.Faktor-faktor tersebut dapat berasal dari internal maupun eksternal masyarakat.Faktor internal perubahan budaya dalam masyarakat dapat berupa sikap masyaakat yang terbuka terhadap budaya baru yang masuk ke masyarakat, ketidakpuasan dengan kondisi yang ada hingga sikap terbuka pada perubahan. Kemudian faktor eksternal yang mempengaruhi faktor perubahan budaya dalam masyarakat diakibatkan karena adanya pengaruh budaya dari wisatawan, masuknya arus globalisasi dan modernisasi, pemerintah yang lebih mendukung dilakukannya ivent-ivent hiburan yang menyebabkan kesakralan suatu 
tradisi makin hilang, adanya inovasi teknologi yang semakin canggih, pengaruh media sosial. Selain faktor diatas, factor intern yang melatarabelakangi perubahan di desa Kuta adalah kurangnya kesadaran pada masyarakat akan kelestarian budaya yang ada, dan dorongan dalam diri individu untuk berubah agar terlihat lebih modern. Sementara factor ekternalnya selain masuknya budaya luar, juga karena factor budaya yang dibawa individu ketika pergi menuntut ilmu atau merantau.

Desa Kuta sebagai salah satu daerah destinasi pariwisata yang ada di pulau Lombok.Pariwisata sendiri merupakan sebuah tempat atau wilayah yang bisa dikunjungi oleh banyak orang.Pariwisata juga merupakan sumber daya alam, budaya atau tempat dimana para wisatawan dapat menikmati keindahan alam atau fasilitas yang disediakan dan banyak dikunjungi oleh touris.Adapun yang mengatakan pariwisata adalah perjalanan untuk melakukan liburab atau rekreasi.

Sebagai salah satu destinasi wisata, desa Kuta memiliki modal atau sumber daya untuk menjadi daerah pariwisata.Sumber daya tersebut adalah sumber daya alam dan budaya, bahkan sumber daya manusia sebagai aktor penggerak pariwisata tersebut.Sumber daya alam yang menjadi objek pariwisata adalah deretan pantai pasir puth seperti pantai kuta, seger, tanjung aan.Selain itu ada budaya yang menjadi obyek wisata seperti tradisi bau nyale, peresean, dan bangunan rumah adat.Sumber daya manusia merupakan salah satu modal penting bagi perkembangan suatu daerah seperti daerah pariwisata, dan seringkali kelompok pemuda yang menjadi sorotan sebagai modal terbesar, potensi tenaga kerja dan aktor pengembangan wilayah.

Kehidupan masyarakat Kuta yang berada di daerah pariwisata tentunya mengalami perubahan dengan perkembangan pariwisata, terutama kehidupan para pemudanya. Kehidupan para pemuda kuta lebih banyak mengarah pada pengembangan pariwisata baik itu sebagai pemandu wisata (guide) ataupun penjaga villa, membudayakan berbicara dengan bahasa inggris, dan pengembangan budaya lokal. Selain itu, perubahan kehidupan pemuda kuta juga terlihat dari gaya hidup, bahasa dan tata karma. Gaya hidup pemuda yang sekarang ini lebih ke arah glamor, perempuan sudah biasa keluar malam, dan kurangnya tata karma atau sopan santun anak muda 
terhadap orang yang lebih tua. Bahkan dengan perkembangan pariwisata yang pesat, disisi lain dampaknya adalah munculnya pekerja anak. Namun disisi lain bagi masyarakat yang memiliki modal, mereka telah membuka café, warung maupun travel.

Kondisi budaya yang ada di Kuta dengan semakin meningkatnya pariwisata untuk saat ini masih tetap dilaksanakan.Tradisi atau kebiasaankebiasaan terdahulu, ajaran tokoh-tokoh adat masih dijalankan.Budaya yang berkembang di desa Kuta tidak jauh bergeser, hanya saja kesakralan budaya tersebut yang mengalami perubahan akibat diadakannya ivent-ivent oleh pemerintah.Salah satu contoh yang mengalami perubahan adalah tradisi menyilaq (mengundang), dulu mendatangi warga langsung kerumahnya sekarang beberapa sudah menggunakan media sosial.Namun masih dominan masyarakat melakukan menyilaq (mengundang) dengan mendatangi langsung ke rumahnya karena kalau menggunakan handphone dianggap tidak etis. Sehingga dapat dikatakan budaya atau tradisi yang ada di desa Kuta tidak banyak mengalami perubahan, namun perubahan gaya hidup pemuda yang tidak dapat terhindarkan.

Faktor yang melatarbelakangi masih dilakukannya budaya, kebiasaan atau tradisi dan aturan adat ditengah pengembangan pariwisata disebabkan oleh tuntutan dari pengembangan wisata itu sendiri, dimana para wisatawan datang ke desa Kuta dikarenakan ingin melihat dan menyaksikan serta menikmati budaya asli yang ada di desa Kuta itu sendiri. Selain itu, karena budaya-budaya tersebut masih diterapkan dan dipertahankan oleh masyarakat dalam kehidupan sehari-hari.

Perubahan aspek budaya dalam kehidupan masyarakat Kuta tidak terlepas dari arus globalisasi. Menurut Ritzer ada tiga paradigma dalam teori yang berbicara tentang aspek budaya globalisasi, sebagaimana diidentifikasi oleh Jan Nederveen Pieterse, yaitu :

Pertama, diferensialisme budaya, menurut Ritzer (dalam Djaya, 2012) bahwa kebudayaan yang ada sebagian besar tidak dipengaruhi oleh globalisasi.Ini bukan berarti kebudayaan tidak mendapat pengaruh prosesproses tersebut, khususnya globalisasi.Tetapi bahwa inti kebudayaan sebagian besar tidak terpengaruh, banyak yang masih tetap seperti sedia kala.Melihat desa Kuta sebagai destinasi pariwisata yang tak terlepas dari 
pengaruh arus globalisasi dan modernisasi, namun ada beberapa tradisi yang masih dipertahankan keasliannya oleh masyarakat setempat. Beberapa budaya asli desa Kuta masih terjaga dengan baik dan tidak tercampur ataupun dipengaruhi budaya luar diantaranya berbagai bentuk kesenian, upacara-upacara adat, hingga cara berpakaian yang memang masih diterapkan oleh masyarakat kuta. Budaya tersebut adalah gendang beleq, madiq mare, ngapung, tomplek, dan cara berpakaian terutama laki-laki ketika ada begawe dengan mengenakan sarung, bebet dan sapuq.

Budaya-budaya asli yang ada di desa kuta tersebut tidak terpengaruh arus budaya luar dikarenakan masyarakat kuta masih menjaga kelestarian dan mempertahankan kesakralan budaya-budaya tersebut.Hal tersebut dikarenakan budaya asli yang mereka miliki menjadi identitas asli bagi masyarakat kuta. Bahkan dalam pelaksanaan budaya tersebut untuk menjaga kesakralan, masyarakat setempat tidak melibatkan pihak luar dan tidak di publish. Masyarakat juga masih mempercayai filosofi dan tidak ingin melanggar aturan budaya-budaya yang sudah ada.Selain itu juga karena para pemangku adat atau para sesepuh yang melestarikan budaya masih hidup.Hal tersebut menjadi faktor yang kuat mengapa budaya asli yang dimiliki masyarakat desa Kuta masih tetap dipertahankan.

Kedua konvergensi budaya, paradigma konvergensi budaya didasarkan pada ide akan globalisasi yang menghasilkan bertambahnya kesamaan di seluruh dunia. Dalam pandangan paradigma ini melihat adanya perubahan kebudayaan-kebudayaan sebagai hasil dari globalisasi.Kebudayaan-kebudayaan dunia dilihat bertumbuh semakin serupa.Menurut Boli dan Lechner (dalam Djaya, 2012) kecenderungan paradigm ini menggerakkan orang melihat adanya asimilasi global yang dominan di dunia.Orang-orang yang bekerja dari perspektif ini berfokus pada hal-hal seperti Imperialisme budaya, Kapitalisme global, Westernisasi, Amerikanisasi, McDonalisasi.Perkembangan pariwisata yang ada di desa Kuta karena dampak globalisasi tentunya membawa perubahan terhadap kehidupan masyarakat. Sebagai wilayah destinasi wisata yang sering didatangi oleh penikmat wisata baik lokal hingga mancanegara, kehidupan masyarakat terutama para pemuda mengalami perubahan lebih kearah westrenisasi. Hal tersebut tercermin dalam kehidupan tour guide yang 
cendrung kebarat-baratan seperti rambut gondrong dan berwarna merah, bertato serta berpakain ala touris. Namun sampai sejauh ini masih amanaman saja dan masih wajar bagi masyarakat setempat. Namun disisi lain perubahan gaya hidup pemuda yang meniru budaya barat seperti gaya berpacaran yang bebas dan suka party malam, hal ini yang sangat dikhawatirkan masyarakat. Selain kehidupan pemuda yang mengalami westernisasi, fasilitas-fasilitas wisata juga mengalami westernisasi. Fasilitas yang tersedia menyerupai kebutuhan gaya hidup ala mancanegara seperti hotel dan café. Dimana fasilitas yang disediakan ada live music di café, dan hal tersebut berdampak pada gaya hidup pemuda.

Westrenisasi yang terjadi di masyarakat desa Kuta disebabkan oleh adanya pengaruh dari luar yang menjadi tuntutan pekerjaan bagi beberapa masyarakat, pengruh budaya luar tersebut diterima dan diterapkan oleh para pemuda sehingga westrenisasi tidak dapat terelakkan.Selain tuntutan pekerjaan, juga karena perkembangan zaman dan globalisasi, dimana perkembangan global ini menjadikan masyarakat mengikuti trend-trend mancanegara.Masyarakat yang sering berinteraksi dengan wisatawan juga menjadi penyebab perubahan yang telah terjadi. Selain karena tuntutan pekerjaan, sikap masyarakat yang tidak peduli atau bodoh amat tentang pandangan orang lain, pengaruh lingkungan, pergaulan, media massa, dan juga karena mengikuti zaman atau trend. Hal tersebut yang meyebabkan terjadinya westernisasi di kalangan anak muda.

Ketiga hibridasi budaya, hibridasi budaya menekankan percampuran kebudayaan-kebudayaan sebagai hasil dari globalisasi dan produksi, dari integrasi kebudayaan-kebudayaan hibrida global dan lokal, yang baru dan yang unik yang tak dapat direduksi menjadi kebudayaan lokal atau global. Konsep yang merupakan inti hibridasi budaya adalah tentang hakikat proses transnasional dari globalisasi, adalah glokalisasi. Robertson (dalam Djaya, 2012) mengadopsi konsep glokalisasi, yang berasal dari istilah pemasaran, untuk mengekspresikan produksi lokal secara global dan lokalisasi global.Berbagai nilai budaya lokal menjadi sangat penting di tengah persaingan global, sehingga perlu adanya pengembangan budaya lokal agar mampu bersaing ditingkat global.Pengemasan budaya lokal menjadi satu hal yang bernilai global disebut dengan glokalisasi.Pada 
masyarakat kuta beberapa kebudayaan lokal juga mengalami glokalisasi seperti perayaan bau nyale yang dikemas menjadi festival terbuka untuk masyarakat umum.

Fenomena glokalisasi pada kebudayaan lokal yang dimiliki oleh masyarakat kuta disebabkan oleh arus globalisasi, perkembangan teknologi dan informasi yang makin pesat untuk saat ini, banyaknya promosi budaya yang diselenggarakan seperti event-event budaya, selain itu peran pemerintah dalam pemasaran dan pengembangan budaya lokal juga menjadi faktor terbentuknya budaya lokal menjadi glokalisasi. Perubahan yang terjadi terutama budaya lokal yang ada di Desa Kuta ini terjadi sejak perkembangan pariwisata sekitar tahun 2017 an, dan dibarengi dengan kemajuan teknologi.Semenjak desa Kuta menjadi daerah destinasi wisata yang ramai dikunjungi wisatawan baik lokal maupun mancanegara, semenjak itulah desa Kuta mengalami perubahan.

Proses krisis (kemerosotan) budaya di kawasan pariwisata juga tak bisa dihindari, termasuk juga bagi kawasan wisata desa kuta, kemerosotan budaya terjadi secara berangsur-angsur. Berawal dari perubahan mata pencaharian masyarakat yang dulunya masyarakat bercocok tanam dan beralih ke pariwisata semenjak kemajuan pariwisata.Dimana tujuan awal masyarakat hanya untuk meningkatkan ekonomi dan pemenuhan kebutuhan hidup.Namun tanpa masyarakat sadari perubahan aspek ekonomi tersebut telah mempengaruhi budaya yang ada di masyarakat.Selain itu kurangnya sosialisasi budaya lokal di lembaga-lembaga dasar seperti lembaga keluarga dan lembaga pendidikan juga mengambil peran dalam kemerosotan budaya lokal di tengah masyarakat kuta.Krisis budaya lokal ini bermula dari desa Kuta yang ditetapkan sebagai daerah destinasi wisata dan mengakibatkan munculnya café-café dan hotel, kunjungan wisatawan yang membawa pengaruh budaya baru dan masyarakat kurang mempertahankan budaya sendiri.

\section{KESIMPULAN}

Faktor yang melatarbelakangi krisis kultural pemuda di kawasan pariwisata diantaranya faktor internal perubahan budaya dalam masyarakat dapat berupa sikap masyarakat yang terbuka terhadap budaya baru yang 
masuk ke masyarakat, ketidakpuasan dengan kondisi yang ada hingga sikap terbuka pada perubahan, kurangnya kesadaran pada masyarakat akan kelestarian budaya yang ada, dan dorongan dalam diri individu untuk berubah agar terlihat lebih modern. Kemudian faktor eksternal yang mempengaruhi faktor perubahan budaya dalam masyarakat diakibatkan karena adanya pengaruh budaya dari wisatawan, masuknya arus globalisasi dan modernisasi, pemerintah yang lebih mendukung dilakukannya iventivent hiburan yang menyebabkan kesakralan suatu tradisi makin pudar, adanya inovasi teknologi yang semakin canggih, pengaruh media sosial, serta faktor budaya yang dibawa individu ketika pergi menuntut ilmu atau merantau.

Krisis kultural pemuda di kawasan pariwisata yang terjadi di desa Kuta tidak terlepas dari pengaruh arus globalisasi dan modernisasi. Hal ini membawa dampak terjadinya diferensialisme budaya, inti kebudayaan sebagian besar tidak terpengaruh, banyak yang masih tetap seperti sedia kala. Beberapa budaya asli desa Kuta masih terjaga dengan baik dan tidak tercampur ataupun dipengaruhi budaya luar diantaranya berbagai bentuk kesenian, upacara-upacara adat, hingga cara berpakaian yang memang masih diterapkan oleh masyarakat kuta. Selanjutnya ada konvergensi budaya, sebagai wilayah destinasi wisata yang sering didatangi oleh penikmat wisata baik lokal hingga mancanegara, kehidupan masyarakat terutama para pemuda mengalami perubahan lebih kearah westrenisasi. Hal tersebut tercermin dalam kehidupan tour guide yang cendrung kebaratbaratan seperti rambut gondrong dan berwarna merah, bertato serta berpakain ala touris. Selain kehidupan pemuda yang mengalami westernisasi, fasilitas-fasilitas wisata juga mengalami westernisasi, seperti hotel dan café. Terakhir ada hibridasi budaya, pengemasan budaya lokal menjadi satu hal yang bernilai global seperti perayaan bau nyale yang dikemas menjadi festival terbuka untuk masyarakat umum.

\section{DAFTAR PUSTAKA}

Demartoto, Argyo, dkk. 2014. Habitus Pengembangan Pariwisata: Konsep dan Aplikasi. Surakarta: UNS PRESS. 
Djaya, Ashad Kusuma. 2012. Teori-Teori Modernitas Dan Globalisasi: Melihat Modernitas Cair, Neoliberalisme, Serta Berbagai Bentuk Modernitas Mutakhir. Bantul: Kreasi Wacana.

Basrowi dan Suwandi. 2008. Memahami Penelitian Kualitatif. Jakarta: Rineka Cipta.

Fashri, Fauzi. 2014. Pierre Bourdieu: Menyingkap Kuasa Simbol. Yogyakarta: Jalasutra.

Hamzah, Amir. 2019. Metode Penelitian Kualitatif: Rekontruksi Pemikiran Dasar serta Contoh Penerapan Pada Ilmu Pendidikan, Sosial dan Humaniora. Batu: Literasi Nusantara.

Herdiansyah, Haris. 2012. Metodologi Penelitian Kualitatif Untuk IlmuIlmu Sosial. Jakarta: Salemba Humanika.

Jones, Pip. 2010. Pengantar Teori-Teori Sosial (Dari Teori Fungsional hingga Post-Modernisme). Jakarta: Obor Indonesia.

Koentjaraningrat. 2002. Kebudayaan, Mentalitas dan Pembangunan. Jakarta: Gramedia Pustaka Utama.

Koentjaraningrat. 2000. Pengantar Ilmu Antropologi. Jakarta: Rineka Cipta.

Muthohar, Sofa. 2013. Antisipasi Degradasi Mora Di Era Globalisasi. Semarang: IAIN Walisongo. (Jurnal Pendidikan Islam Vol. 7, Nomor 2, Oktober 2013).

Peursen, C. A. Van. 1988. Strategi Kebudayaan. Yogyakarta: Kanisius.

Pitana, I Gde dan Gayatri, Putu G. 2005.Sosiologi Pariwisata: kajian Sosiologis terhadap Struktur, Sistem, dan Dampak-Dampak Pariwisata. Yogyakarta: ANDI.

Ritzer, George. 2010. Teori Sosial Modern. Yogyakarta: Kreasi Wacana.

Silalahi, Ulber. 2009. Metode Penelitian Sosial. Bandung: Refika Aditama.

Silitonga, Sabar M. 2013. Krisis Nilai Budaya Menurut Pandangan Kristen. Universitas Medan: JUPIIS Vol. 5 No. I Juni 2013.

Soekanto, Soerjono. 2002. Sosiologi Suatu Pengantar. Jakarta: Raja Grafindo Persada. 